\title{
The Impact of Monetary Policy on Current Account Balance In Nigeria
}

\author{
${ }^{1}$ Danmola, Rasaq Akonji, ${ }^{1}$ Olateju, Adijat Olubunkola \\ ${ }^{I}$ Department of Economics, Lagos State University, Ojo, Lagos, Nigeria
}

\begin{abstract}
The study examine the impact of monetary policy on the current account's components for the period 1970-2010 in Nigeria. The study employs Johasen Cointegration, Ordinary Least Square Method (OLS) and Error Correction Model, and the study confirms a long-run relationship between monetary policy (proxy by money supply) and components of current account under consideration. Money supply positively influences all the variables expect exchange rate that is negative. The study further shows that money supply significantly influences exports, imports and industrial output at 5\% level of significant. The error correction model shows an appropriate sign, indicating that over 30 percent of the of the last year's shock is adjusted back to the longrun equilibrium association in the present year. The study therefore suggest monetary policy measures that help in providing clear-cut incentives in the importation of industrial raw-materials and equipment and expansion in the volume of exports, so as to reduce the deficit in the current account balance.
\end{abstract}

Keywords: Monetary policy, Current Account Balance, Cointegration and Error Correction Model.

\section{Introduction}

The current account balance of any country assumes a significant dimension in the financial position of the country, and in fact, it determines the economic performance and the quality of management of such economy. The current account balance illustrate the country's aggregate net trade in goods and services, the net earnings from other factor services such as rents, interest, profits and dividends and also includes net transfer payments and which includes funds accrued from pension funds and net workers' remittances from abroad. The economy over the years exhibited a culture of having current account imbalance and which in most cases in deficit and also with huge external debts obligation and which grew from $\$ 170,000$ in 1970 to $\$ 294,614$ million in 1990 and rose to $\$ 2,695,072$ million in 2005 before it was reduced to $\$ 451,461$ million in 2006 , only for the country to continue to engage in external borrowing [1]. The issue of current account imbalance occasioned by the continue accumulation of external debts have generated some interest, which have necessitated the need to examine the sustainability of Nigeria's current account imbalance.

The emergence of petroleum sector as dominant sector in 1970s has moved the economy from being an agrarian economy to an oil-based economy and with attendance neglect of the agricultural sector. The oil sector in the 1970s have experience a tremendous boom for the Nigerian economy, moving its contribution to the GDP from 2.5 percent in 1960 to 12 percent in 1970 and moved further to over 90 percent in 1990s[1]. The prevalence of oil sector as a dominant sector in the economy in 1980s and 1990s reflected the significant rise in the world oil price and the expansion in the volume of revenue generated by the government, which necessitated the increase in size of government expenditure, in terms of adjusting the wage rate in the public sector and by extension the private sector as well. The demand-pull inflation generated by the public sector wage increase and coupled with the cost-push impact caused by private sector wage increase led to the general price increase. But the fixed exchange rate in place in 1970s and early 1980s necessitated further increase in aggregate demand in the economy and consequently impacted negatively on current account balance in Nigeria.

Moreover, with the over-reliance on petroleum sector, the oil sector took a dramatic turn, when the market witnessed a downward trend in price level and with Nigeria heavy dependence on imported manufacturing goods, this further put pressure on our current account balance. In addition, the unrealistic exchange rate regime in place in 1980s further aggravates the situation, which further put pressure on our current account balance. The period equally witnessed massive short and medium term borrowing on the part of the government and which worsen the country's current account balance. The period marked the complete failure of fixed exchange rate regime and policy drift becomes imperative in the way of flexible exchange rate and also other policies measures such as structural adjustment programme were put in place. The essence of those policies was to restructure and diversify the productive base of the economy and reduce over dependence on the petroleum sector. The period witnessed massive devaluation of country's currency through auctioning at the open market.

Furthermore, the country embarked on numerous policies aiming at reducing government over bearing on the economy, and policies that focused on government continued control of the economy were abandoned in favour of free economy and this commenced in 1986 with the policy of structural adjustment programme. The 
over bearing influence of government in term of control of production, interest determination and maintaining of fixed exchange rate were eliminated. To encourage private participation and promote structural reform, government in 2003, initiated the policy of National Economic Empowerment and Developments (NEEDS). The policy includes comprehensive macroeconomic policies that provides conducive atmosphere in order to accelerate economic growth and development and which further enhance external account position.

\section{1:1 Monetary Policy Transmission Mechanism}

Monetary policy referred to various policy instruments to be implemented by monetary authority i.e central bank, the policy that target supply and availability of money with the aim at reducing unemployment and controlling inflation. Monetary policy instruments can only be more effective through the influence of aggregate demand, which its impact on money supply is limited depending on the degree of interest rate pass-through and the level of price rigidities in the economy. Many channels of monetary transmission mechanism have been identified in literature but the performance and effectiveness of these channel mechanisms varies from one country to another.

[2] and [3], they believed that interest rate channel as part of monetary mechanism operate through the effect of monetary shocks on liquidity conditions and real interest rate and which in turn affect part of aggregate demand like investment and consumption. Although, interest rate channel as an already established mechanism, it may not be used in isolation to explain variations or fluctuation in out-put particularly in a small open economy.

[4] and [5] , provides an explanation on how bank lending (or credit) channel works through the credit aggregate, react to change in interest rate and other policy instruments. They established that credit channel further extent to interest rate and amplifies the real effect on monetary policy through the changes that occur in the bank credit that are given in form loans and advances. For credit channel to be more effective as monetary mechanism, the important role of banks as a source of working capital for private sector must be sustained, most especially in emerging economies.

[2], explained that exchange rate channel works through the effect of change in monetary development on exchange rate and aggregate demand and supply. In some cases, a rise in interest rate would normally lead to an appreciation of the exchange rate and reduce pressure on price of imported goods and services and hence, lower the domestic inflation. The effectiveness of the exchange rate regime depends on the type of exchange rate regime in place. The rest of the paper includes Section 2-Literature reviews, Section 3- Data source and Model specification, Section 4-Methodology, Section 5 Data analysis and interpretation of result and Section 6Conclusion.

\section{Literature Review}

Many works have been done to examine the impact monetary policy options available for the country in reducing pressure on the country's current account balance. The work of Alfred Marshall and Abba lerner in providing theoretical basis for J-curve hypothesis states that if initially the balance of trade is zero, and if supply elasticities are infinite, then, the absolute value of export and import demand elasticities have to be at least large enough to add-up to unity to have an exchange rate devaluation that will bring about the surplus in balance of payment. J-curve hypothesis tries to explain on how trade variable like import and export react to the devaluation of country's currency. The depreciation of country's currency in the short-run generate deficit in the current account and increase in import, but with the country having more access to international market and having more commodities that can compete favourably with foreign competitors, the net effect of this is that cost of production will reduce after some period and subsequently, increase the volume of export and with increase in price of importation; this will positively affect current account balance and J-curve hypothesis concluded that the country' currency may get back to the appreciation.

[6] He opined that J-curve hypothesis can be justified when examining the change in elasticity over time, the elasticities are small in the short-run, making Marshall-Lerner condition less likely to be satisfied, but in the long-run, elasticities become larger, ultimately crossing the threshold point described by Marshall-Lerner, thus creating the condition for improvement in balance of payment.

[7] they analyse the use of open macroeconomic model in the case of China and discovered that expansionary monetary policy generate growth in both output and permanent price level in short-period. It equally found that an international imbalance have high significant effect with China's exchange rate appreciation.

[8] in his paper, he found that negative relationship exist between current account balance and set of macroeconomic variables like inflation, income and degree of openness in Nigeria. The study further identified the positive relationship between current account balance and net foreign assets, budget deficit and exports.

[9] examine a two-sector in small open economy, using general equilibrium approach of expectation, they discovered that current account sensitivity to monetary policy shocks is due to elasticity of substitution 
among investment, consumption and risk aversion and that, current account efficient response to technological shocks. But in the case of advance countries like U.K. Italy and France, the monetary policy shocks react on balance of trade caused by expenditure switching effect and they also found from their study a little support for J-curve effect and this evidence was further supported by [10].

[11] examine the current account dynamics and exchange rate behavior in Jamaica. Their findings show that change in real exchange rate exact significant influence on economic activities by changing the relative returns in the tradable and non-tradable sectors.

[12] examine the twin deficit hypothesis in Indonesia, Malaysia, the Philippines and Thailand; they established a long-run relationship between budget deficit and current account. The result of their research shows a unidirectional causality, which run from budget deficit to current account in Thailand. In Indonesia, current account targeting was discovered, while in Malaysia and Philippines, the causality was bidirectional.

\section{Data Source and Model Specification}

The study will employ time series data from 1970-2010. The data will be collected from central bank of Nigeria statistical bulletin of various issues and supplemented by data from National Bureau of Statistics. The variables used in the study are defined as follows: IND represents industrial output, EXH represents nominal exchange rate, $\mathrm{M}$ represents import, $\mathrm{X}$ represents export, $\mathrm{CPI}$ represents consumer price index, MS denotes monetary aggregate $\mathrm{M} 2$ and $\mathrm{RI}$ denotes short term real interest.

$$
M S=d_{0}+d_{1} I N D+d_{2} C P I+d_{3} E X H+d_{4} M+d_{5} X+d_{6} R I+q_{7} E X H \mu-\cdot-\cdot-\cdot--1
$$

\section{Methodology}

Generally, it has been established in literature [13] that time series data are non-stationary and with traditional approach of ordinary least square (OLS), give rise to the emergency of spurious regression. The problem of non-stationary can be resolved by differencing the time series variables. in examining the long-run relationship among the variables, cointegration and error correction model would be conducted to establish whether such long-run relationship exist. Cointegration method solve the problem associated with the spurious regression and Error correction models reflect short-run dynamics and attempt to show casual relationship. In attempt to test for the stationary of the data, Augmented Dickey Fuller (ADF) and Phillip Peron (PP) tests will be carried out as unit tests for testing the stationary and non-stationary of the series. The unit root testing the subsequent regression equation:

$$
\Delta \mathbf{Y}_{\mathbf{t}}=\alpha+\beta_{1} \mathbf{Y}_{\mathrm{t}-\mathbf{1}}+\mathbf{t}+\boldsymbol{\Sigma} \boldsymbol{\beta} \mathbf{2} \Delta \mathbf{Y}_{\mathrm{t}-\mathrm{k}}+\boldsymbol{\mu}_{\mathrm{t}}--------------------2
$$

Where $\mathrm{Y}_{\mathrm{t}}=$ time series, $\Delta=$ first difference, $\mathrm{t}=$ linear trend $\alpha=$ constant and $\mu_{\mathrm{t}}=$ error term.

The null hypothesis of unit root is $\mathrm{o}=\beta$, if a variable is said to be non-stationary, then, it may be further tested for stationary at first difference, then bivariate cointegration test be implied to recognize the relationship between variables. since we are dealing with multivariate model, we are dealing with, then Johassen cointegration test become imperative. This cointegration is used to ascertain the number of cointegrating vector (Kerry Patterson) and this reflect that there must be existence of an error correction model and which can be represented as

$$
\Delta M S=\Upsilon_{0}+\Upsilon_{1} \Delta I N D+\Upsilon_{2} \Delta C P I+\Upsilon_{3} \Delta E X H+\Upsilon_{4} \Delta M+\Upsilon_{5} \Delta X+\Upsilon_{6} \Delta R I+\Upsilon_{7} N F P+\mu_{t}--------3
$$

\section{Data Analysis and Interpretation of Results}

Recent analyses of macro economies data are non-stationary and to avoid spurious and unpredictable forecast, it become imperative to verify their stationarity or whether they are integrated at different orders. To verify whether they are stationary or not, we subject the variables to unit root tests using both augmented dickey fuller test (ADF) and Phillip pheron (PP) tests.

Table 1a: ADF Unit Root Test-Trend and Intercept

\begin{tabular}{|l|l|c|c|c|}
\hline Variable & $\begin{array}{l}\text { ADF Test } \\
\text { Statistics }\end{array}$ & Critical Values & Level of Sig & Order of Integration \\
\hline MS & -4.36 & -4.21 & $1 \%$ & $1(1)$ \\
\hline CPI & -3.59 & -3.54 & $5 \%$ & $1(1)$ \\
\hline IND & -12.45 & -4.21 & $1 \%$ & $1(0)$ \\
\hline M & -7.95 & -4.21 & $1 \%$ & $1(0)$ \\
\hline NFP & -7.11 & -4.22 & $1 \%$ & $1(0)$ \\
\hline RI & -5.89 & -4.22 & $1 \%$ & $1(0)$ \\
\hline X & -7.67 & -4.21 & $1 \%$ & $1(0)$ \\
\hline EXH & -5.05 & -4.32 & $1 \%$ & $1(1)$ \\
\hline
\end{tabular}

Source: Author's computation 
The Impact Of Monetary Policy On Current Account Balance In Nigeria

Table 1b: PP Unit Root Test-Trend and Intercept

\begin{tabular}{|c|c|c|c|c|}
\hline Variable & $\begin{array}{ll}\text { PP } & \text { Test } \\
\text { Statistics } & \end{array}$ & Critical Values & Level of Sig & Order of Integration \\
\hline MS & -4.24 & -4.21 & $1 \%$ & 1(1) \\
\hline CPI & -3.66 & -3.54 & $5 \%$ & 1(1) \\
\hline IND & -5.72 & -4.21 & $1 \%$ & $1(0)$ \\
\hline $\mathrm{M}$ & -3.80 & -3.53 & $5 \%$ & $1(0)$ \\
\hline NFP & -3.88 & -3.53 & $5 \%$ & $1(0)$ \\
\hline RI & -6.99 & -4.21 & $1 \%$ & 1(1) \\
\hline $\mathrm{X}$ & -7.61 & -4.21 & $1 \%$ & 1(1) \\
\hline EXH & -5.05 & -4.32 & $1 \%$ & $1(1)$ \\
\hline
\end{tabular}

Source: Author's Computation

The above unit root tests are carried under both ADF and PP, using the ADF, the IND, M, NFP, RI and $\mathrm{X}$ are found to be stationary at level and $1 \%$ level of Significant respectively. While CPI, EXH and MS are found to be stationary at first difference at $5 \%, 1 \%$ and $1 \%$ level of significant respectively. But under PP, IND, $\mathrm{M}$, and NFP are stationary at a level and at $1 \%, 5 \%$ and $5 \%$ level of significant, while MS, CPI, RI, X and EXH are found to be stationary at first difference and at 1\%,5\%,1\%,1\%,1\% and $1 \%$ level of significant respectively. Having established the stationary of the variables, then we test for the long-run relationship among the variables through the use of Johasen test of Cointegration and which is tested below under both trace value and Eigen-Maximum value.

Table 2a: Johasen Cointegration Test (Trace Value)

\begin{tabular}{|c|l|l|c|c|}
\hline Null Hypothesis & Alternative Hypothesis & Maximum statistic & Critical Value & P-Value \\
\hline $\mathrm{r}=0$ & $\mathrm{r}=1$ & 661.9850 & 159.5297 & 0.0000 \\
\hline $\mathrm{r}=1$ & $\mathrm{r}=2$ & 445.6994 & 125.6154 & 0.0001 \\
\hline $\mathrm{r}=2$ & $\mathrm{r}=3$ & 262.1259 & 95.7537 & 0.0000 \\
\hline $\mathrm{r}=3$ & $\mathrm{r}=4$ & 138.2704 & 69.8189 & 0.0000 \\
\hline $\mathrm{r}=4$ & $\mathrm{r}=5$ & 69.1091 & 47.8561 & 0.0000 \\
\hline $\mathrm{r}=5$ & $\mathrm{r}=6$ & 30.4195 & 47.8561 & 0.0002 \\
\hline
\end{tabular}

Trace test indicates 6 Cointegrating equations at 0.05

Source: Author's Computation

Table 2b: Johasen Cointegration Test (Eigen Value)

\begin{tabular}{|c|l|l|l|l|}
\hline $\begin{array}{l}\text { Null } \\
\text { hypothesis }\end{array}$ & $\begin{array}{l}\text { Alternative } \\
\text { Hypothesis }\end{array}$ & $\begin{array}{l}\text { Maximum } \\
\text { Eigen Statistic }\end{array}$ & Critical Value & P-Value \\
\hline $\mathrm{r}=0$ & $\mathrm{r}>1$ & 216.2856 & 53.3626 & 0.0001 \\
\hline $\mathrm{r}=1$ & $\mathrm{r}>2$ & 183.5735 & 46.2314 & 0.0000 \\
\hline $\mathrm{r}=2$ & $\mathrm{r}>3$ & 123.8556 & 40.0776 & 0.0000 \\
\hline $\mathrm{r}=3$ & $\mathrm{r}>4$ & 69.16123 & 33.8769 & 0.0000 \\
\hline $\mathrm{r}=4$ & $\mathrm{r}>5$ & 38.6897 & 27.5897 & 0.0013 \\
\hline
\end{tabular}

Maximum EigenValue test indicates 5 Cointegrating equations at 0.05

Source: Author's Computation

The above shows the Johasen test for Cointegration, to establish the long-run relationship among the variables. The above trace value test indicates 6 Cointegrating equations at 5\% level of significant, while Maximum Eigen test indicates 5 Cointegrating equations at $5 \%$ level of significant. With this, we further proceeds to run an ordinary least square regression to explain the relationship between money supply and other variables in the country's current account balance and this can shown below:

Table 3: Regression Result of the Model

\begin{tabular}{|l|l|l|l|c|}
\hline Variable & Coefficient & Std.Error & t-statistic & Prob. \\
\hline C & -78902.42 & 184762.0 & -0.427049 & 0.6721 \\
\hline CPI & 1975 & 8396179 & 0.235240 & 0.8155 \\
\hline EXH & -9199.440 & 5565.337 & -1.652988 & 0.1078 \\
\hline IND & 0.046821 & 0.011205 & 4.178594 & 0.0002 \\
\hline M & 0.422679 & 0.204152 & 2.070413 & 0.0463 \\
\hline NPF & 0.159979 & 0.216553 & 0.738752 & 0.4653 \\
\hline
\end{tabular}


The Impact Of Monetary Policy On Current Account Balance In Nigeria

\begin{tabular}{|l|l|l|l|l|}
\hline RI & 6038.205 & 17141.81 & 0.352250 & 0.7269 \\
\hline$X$ & 0.593150 & 0.174961 & 3.390185 & 0.0018 \\
\hline
\end{tabular}

\begin{tabular}{|l|l|l|c|}
\hline R-squared & 0.961086 & Mean dependent Var. & 1260110 \\
\hline Adjusted R-squared & 0.952831 & S.D dependent Var. & 2543044 \\
\hline S.E of Regression & 552307.3 & Akaike info Criterion & 29.45478 \\
\hline F-statistic & 116.4314 & Durbin-watson Sta. & 1.271711 \\
\hline Prob(F-Statistic) & 0.0000 & & \\
\hline
\end{tabular}

Source: Author's Computation

From the table of regression above, the estimation shows there is positive relation between all the variables above expect exchange rate which is negative, and this is expected. This is so because increase in money supply without corresponding increase in the of productivity as will have in Nigeria will impact negatively on the exchange rate and from above, industrial output is just about $04 \%$ to the $100 \%$ in money supply. Also the relationship between money supply, industrial output and export are statistically significant but the relationship between money supply, imports, consumer price index, exchange rate, net factor payments and short interest rate were not statistically significant.

R-squared is the coefficient of determination, showing the percentage of variation that was accounted for by the variation in the explanatory powers of the model. A close examination of the table above indicates that the model has a fairly high coefficient of determination. R-square from the above is 96 percent i.e the Rsquare reported that the variables can explain about 96 percent of total variation in money supply and the remaining 4\% variation in money supply are not accounted for in model or rather accounted by the variables outside the model. More so, F-value is quite high that the model adequately explained over 90 percent of the situation of money supply and it is quite significant at $1 \%$. The Durbin-Waston statistic was not substantially farther away from the traditional benchmark of 2.0.

Table 4: Vector Error Correction Model

\begin{tabular}{|l|l|l|}
\hline & D(MS) & t-statistic \\
\hline Intercept & 2670932 & 8.1046 \\
\hline D MS (-1) & -2.20793 & -4.95050 \\
\hline D CPI (-1) & -5137.98 & -6.08832 \\
\hline D EXH (-1) & -266.9142 & -0.1118 \\
\hline D IND (-1) & -1.306570 & -9.25844 \\
\hline D M (-1) & 1.289321 & 3.87029 \\
\hline D NPF (-1) & & -3.72369 \\
\hline D RI (-1) & -21775.18 & -2.09482 \\
\hline D X (-1) & 0.358746 & 3.32017 \\
\hline ECT (-1) & -0.310500 & -800864 \\
\hline
\end{tabular}

\section{Source: Author's Computation}

From the above, the estimated lagged ECM (-1) is negative and which is conformity with appropriate sign. The ECM result supports the cointegration of the variables exhibited in the Johasen cointegration tests conducted under both the trace and maximum eigen values. The feedback on the ECM (-1) coefficient is -0.31 , which implies a normal adjustment processes. It means that over $31 \%$ of the disequilibria of the earlier year's shock adjust back to the long-run equilibrium association in the present year.

\section{Conclusion}

The research work studied the impact of Central Bank of Nigeria's monetary policy as proxy by the money supply on the current account balance. The study confirmed that the money supply have positive and significant influence on both the import and export, while at the same time exact less influence on industrial output though positive. The influence of the money supply on exchange rate is negative and most especially when the currency continue to depreciate with the policy of flexible exchange rate introduced by the federal government in the mid-of 1986. It also instructive for the government to embark on policy that will enhance industrial production and at same time encourages exportation of industrial goods. For the country to reduce deficit on the current account position, she must intensified aggressive monetary policy that that will both encourage industrial production and further provides incentives for export expansion.

More so, the allocation of foreign exchange for importation must be done with caution and efforts must be in direction of importation of industrial raw-material and industrial equipment that will enhance the domestic production, rather than importation of finished goods, which further worsen our current account balance position. 


\section{Refrences}

[1] Central Bank of Nigeria Statistical bulletins Various Issues.

[2] Talylor, J, “The Monetary Transmission Mechanism: An Empirical Framework”, Journal of Economics Perspectives, Vol.9, 1995, PP. 11-26.

[3] Mishkin, F. "The Channels of Monetary Transmission: Lessons for Monetary Policy”, NBER Working Paper, No 5464 (Cambridge, M.A: National Bureau for Economic Research).

[4] Bernanke, B., and A., Blinder, "The Federal Funds Rates and the Channels of Monetary Transmission", American Economic Review Vol.82, 1992 PP. 901-921.

[5] Bernanke, B., and M., Gertler, "Inside the Black Box: the Credit Channel of Monetary Transmission", Journal Economic Perspectives, Vol.9, 1995 PP27-48.

[6] Kulkarni, K. "Readings in International Economics. New Delhi: Serial Publication 2007.

[7] Devereux, M. B. and H., Genberg, "Current Appreciation and Current Account Adjustment", HKIMR Working paper No17/2006.

[8] Chete, L. N. "Explaining Current Account Behaviour in Nigeria", the Nigerian Journal of Economic and Social Studies, 43, 2001, PP 219-238.

[9] Lu and Min "Current Account Dynamics and Optimal Monetary Policy in a Small-Open Economy”, international Journal of Monetary Economics and Finance, Vol.12, Number 2, 1 May, 2009, PP 166-193 (28)

[10] Soyoung K. "Effect of Monetary Policy Shocks on the trade balance in Small-Open European Countries", Economics Letters 571, 2001, 197-203.

[11] Henry, C., and R. Long more "Current Account and Real Exchange Rate dynamic, the Jamaica Experience", Bank of Jamaica Working Papers, 2003.

[12] Baharumshal, A. Z., Lau, E. and A. M. Ichalid, "Testing Twin Deficits Hypothesis: Using VAR and Variance Decomposition", 2000 .

[13] Maddala, G. S. "Introduction to Econometrics $3^{\text {rd }}$ Edition (India: Replika Press PVT Ltd. 2000) 